\title{
Effect of Acidification on Metal Uptake of Picea abies Seedlings
}

\section{Päivärinta, J.}

Springer-Verlag New York Inc.

1994

Päivärinta, J. and Lodenius, M. 1994. Effect of Acidification on Metal Uptake of Picea abies

Seedlings. Bulletin of Environmental Contamination and Toxicology 52: 444-451.

http://hdl.handle.net/1975/189

Downloaded from Helda, University of Helsinki institutional repository.

This is an electronic reprint of the original article.

This reprint may differ from the original in pagination and typographic detail.

Please cite the original version. 


\title{
Effect of Acidification on Metal Uptake of Picea abies Seedlings
}

\author{
J. Päivärinla, M. Lodenius
}

Department of Limnology and Environmental Protection, P.O. Box 27, SF-00014 University of Heisinki, Finland

The effects of air pollutants on forest ecosystems are based on complex interactions where no single dominating factor has been found. The reasons for forest die-back are extremely difficult to determine because of the lack of long-term data and the difficulties in determining the "normal" state of the forest ecosystems (Krause et al. 1986). The forest die-back in central Europe has been interpreted on the basis of many different theories, including so called stress hypothesis. According to this hypothesis all stress factors are summed together so that the limits of biological stress tolerance of different organisms can be exceeded (Schulze 1989). One potential stress factor is soil acidification (Godbold and Hüttermann 1986, Bergkvist 1987). Anthropogenic pollutants increase soil acidification, which is known to increase the solubility of many metals. This has raised the question whether metals could be one potential stress factor to forest organisms. Root growth and the uptake of nutrients and water are in some cases sensible parameters of metal toxicity (Godbold and Hüttermann 1986). Although it is evident that metals are not the main factor in forest decline, it is important to understand the role of metals as a stress factor on forest ecosystems.

Metal uptake by different plant species, especially trees, is unclear (Martin and Coughtrey 1982, Smith and Brennan 1984, Kabata-Pendias 1992). For example the synergistic and antagonistic effects of different metals in plant tissues and the availability of organic metal complexes are still unknown. Plant roots also play an important active role in mobilizing metals from soil particles by producing organic compounds that are effective in releasing substances bound to soil particles (Kabata-Pendias 1992). It is important to study the quantities of metals taken up by forest plants because plants are one way for soil metals to enter forest food chains. It is also important to know whether metals can accumulate into plants in concentrations harmful to the plant itself. This study was designed to determine whether metal uptake by Norway spruce (Picea abies Karst.) is dependent on acidification or humus content of the soil. 
Two different soils were used in the experiment: "sand" and "bumic". They were prepared by mixing sieved ( $2-\mathrm{mm}$ mesh) sand and homogenized, unlimed peat. The first soil had a sand:peat proportion of 8:1 (vol:vol) and the other soil 2:1. The final densities of the soils were 1.58 and $1.36 \mathrm{~g} / \mathrm{ml}$, respectively. The sand and peat were mixed thoroughly and separately for each seedling. The soil quality in the beginning of the experiment is shown in Table 1.

Table 1. Soil quality before treatments; the concentrations of soluble elements were measured after digestion in $\mathrm{NH}_{4} \mathrm{COOH}-\mathrm{EDTA}$ (pH 4.65).

\begin{tabular}{|l|c|c|}
\hline & "Sand" & "Humic" \\
\hline Conductivity, $\mu \mathrm{S} / \mathrm{cm}$ & 0.18 & 0.38 \\
\hline Organic matter, \% of dry weight & 1.1 & 2.9 \\
\hline Soluble $\mathrm{P}, \mathrm{mg} / \mathrm{l}$ & 1.6 & 2.4 \\
\hline Soluble $\mathrm{N}, \mathrm{mg} / \mathrm{l}$ & 17 & 33 \\
\hline Soluble $\mathrm{K}, \mathrm{mg} / \mathrm{l}$ & 26 & 26 \\
\hline Soluble $\mathrm{Ca}, \mathrm{mg} / \mathrm{l}$ & 140 & 160 \\
\hline Soluble $\mathrm{Mg}, \mathrm{mg} / \mathrm{l}$ & 16 & 29 \\
\hline
\end{tabular}

Three-year-old seedlings of Norway Spruce (Picea abies) were planted in pots (4.5 I of soil in a $5 \mathrm{l}$ pot) in a greenhouse (glass roof, no walls) in spring 1988. During the growth periods in 1988 and 1989, the climate was near outdoor conditions. During the winter they were kept in a dark laboratory in the cold $\left(+0^{\circ} \mathrm{C}\right.$, humidity $\left.70 \%\right)$.

The spruce seedlings were subjected to three different treatments:

- $\quad$ artificial acidification, $\mathrm{pH}$ approx. 6 (distilled water + nutrients $=\mathrm{D}$ )

- $\quad$ artificial acidification, pH 5.4 (simulating North European rain $=\mathrm{N}$ )

- $\quad$ artificial acidification, pH 3.6 (simulating Central European rain $=\mathrm{C}$ )

Laboratory prepared water was added directly to the soil once a week in amounts corresponding to an annual precipitation of $650 \mathrm{~mm}$. This artificial precipitation was prepared by adding $\mathrm{KCl}(25 \mathrm{mg} / \mathrm{l}), \mathrm{NaCl}(38 \mathrm{mg} / \mathrm{l}), \mathrm{CaSO}$, $(99 \mathrm{mg} / \mathrm{l}), \mathrm{MgNO}_{3}(18 \mathrm{mg} / \mathrm{l})$ and $\mathrm{NH}_{4} \mathrm{SO}_{4}(29 \mathrm{mg} / \mathrm{l})$ to distilled water. The $\mathrm{pH}$ was adjusted by adding $\mathrm{H}_{2} \mathrm{SO}_{4}$ and $\mathrm{HNO}_{3}$ (Lodenius and Autio 1989). Six individual seedlings were subjected to the same treatment. Samples were taken in September 1989 from soil, roots ( $\varnothing<0.1 \mathrm{~mm}$ ), needles 1989 and needles 1988. The root samples were washed in distilled water $(400 \mathrm{ml}$ in a shaker bath at $300 \mathrm{rpm}$ for $5 \mathrm{~min}$ ). All samples were dried and stored in paper bags. 
The samples were homogenized and dried over night at $+105^{\circ} \mathrm{C}$. They were digested in $\mathrm{HNO}_{3}\left(2.5\right.$ hours at $+50^{\circ} \mathrm{C}, 4$ hours at $+105^{\circ} \mathrm{C}$ and 4 hours at $+180^{\circ} \mathrm{C}$ ). After filtration and dilution the samples were analyzed by graphite furnace A'AS (Cd) or flame AAS (Fe, Mn, Zn, Cu, Al; Varian SpectrAA 40 and Perkin Elmer 360). The acid treatment used here does not dilute silicates, which is refelected as a lower recovery for $\mathrm{Al}$ in the standard plant samples (Table 2). The amounts of plant-available elements were analyzed from soil samples after digestion by $\mathrm{NH}_{4} \mathrm{COOH}$ - EDTA at pH 4.65.

\begin{tabular}{|c|c|c|c|c|c|c|}
\hline & $\mathrm{Fe}$ & $\mathrm{Mn}_{\mathrm{n}}$ & $\mathrm{Cu}$ & $\mathrm{Zn}$ & $\mathrm{Cd}$ & Al \\
\hline $\begin{array}{c}\text { A cert. } \\
\text { own }\end{array}$ & $\begin{array}{l}200 \pm 10 \\
180 \pm 4.3 \\
\end{array}$ & $680 \pm 8.1$ & $\begin{array}{r}3.0 \pm 0.3 \\
3.9 \pm 0.24 \\
\end{array}$ & - & $\begin{array}{c}<0.5 \\
0.20 \pm 0.009\end{array}$ & $\begin{array}{c}545 \pm 30 \\
440 \pm 18\end{array}$ \\
\hline $\begin{array}{l}\text { B cert. } \\
\text { own }\end{array}$ & . & $\begin{array}{c}57.0 \pm 2.4 \\
57 \pm 2.0\end{array}$ & $\begin{array}{r}46.6 \pm 1.8 \\
44 \pm 2.3\end{array}$ & $\begin{array}{l}16.0 \pm 0.7 \\
18 \pm 1.8\end{array}$ & $\begin{array}{l}0.10 \pm 0.02 \\
0.07 \pm 0.01\end{array}$ & $\begin{array}{l}450 \pm 20 \\
310 \pm 36\end{array}$ \\
\hline
\end{tabular}

\section{RESULTS AND DISCUSSION}

The soil pll-values were affected as follows:

$\begin{array}{lcc} & \text { "SAND" } & \text { "HUMIC" } \\ \text { Beginning } & 4.6 & 4.2 \\ \text { Distilled water } & 4.6 & 4.1 \\ \text { pII 4.4 } & 4.7 & 4.2 \\ \text { pH 3.6 } & 4.4 & 4.0\end{array}$

The strongest acid treatment lowered the $\mathrm{pH}$ value only $0.2 \mathrm{pH}$ units. It is obvious that the buffering capacity of the soil was sufficient to eliminate the effect of acid addition to the $\mathrm{pH}$ value. Neither treatment had significant effects on the Fe levels of the plant tissues (Fig. 1).

Acidification had no significant effect on plant Mn-levels, but Mn-levels were significantly higher in plants growing in more humus-containing soils (Fig. 2). In general the seedlings seemed to concentrate $\mathrm{Mn}$ in the needles rather than in roots.

Copper concentrated in the roots (Fig 3 ). The copper concentrations in plant tissues were not affected by the acid treatment or the soil organic matter content.

Zinc concentrated in the plant needles rather than roots (Fig. 4). This is not surprising because $\mathrm{Zn}$ is a component in at least 20-30 enzymes situated especially in plant leaves (Hewitt 1983). 


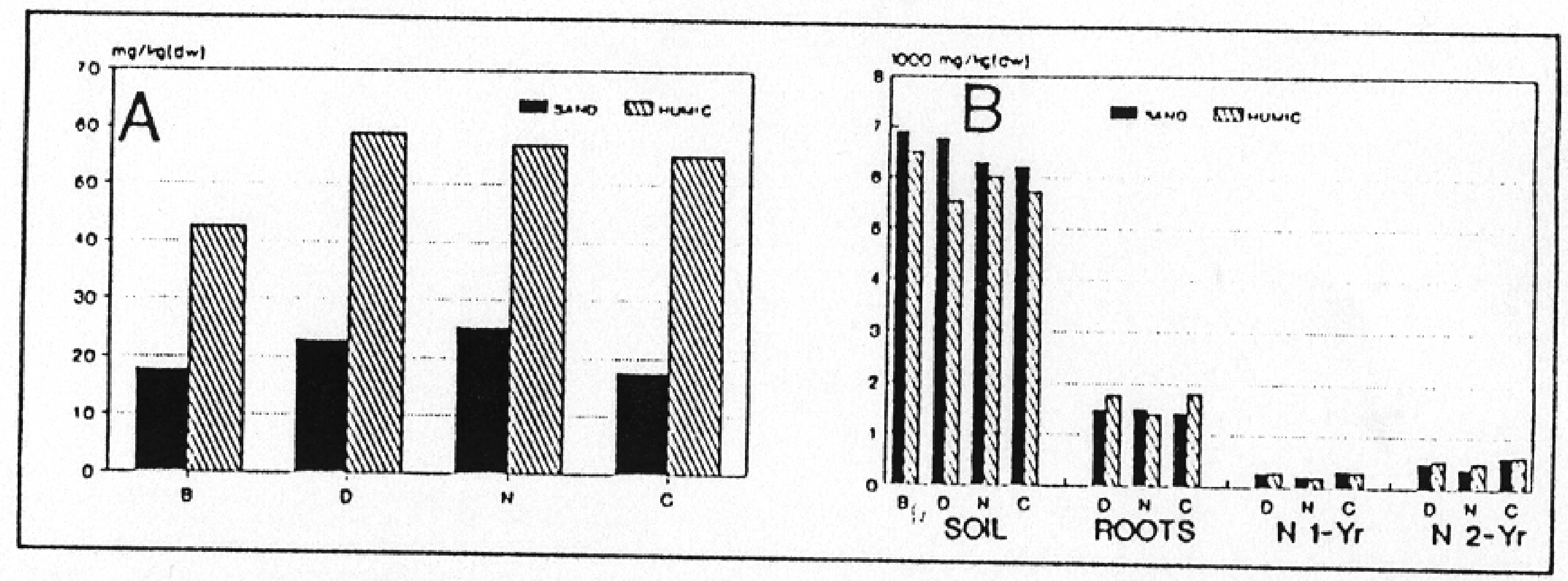

Figure 1. A: Plant-available iron in soil $(B=$ beginning, $D=$ distilled water + nutrients, $N=$ north-European rain, $\mathrm{C}=$ central European rain). $\mathrm{B}$ : Fe concentrations in soil (tot $\mathrm{Fe}$ ) and in plant roots and needles of one year and two years of age.

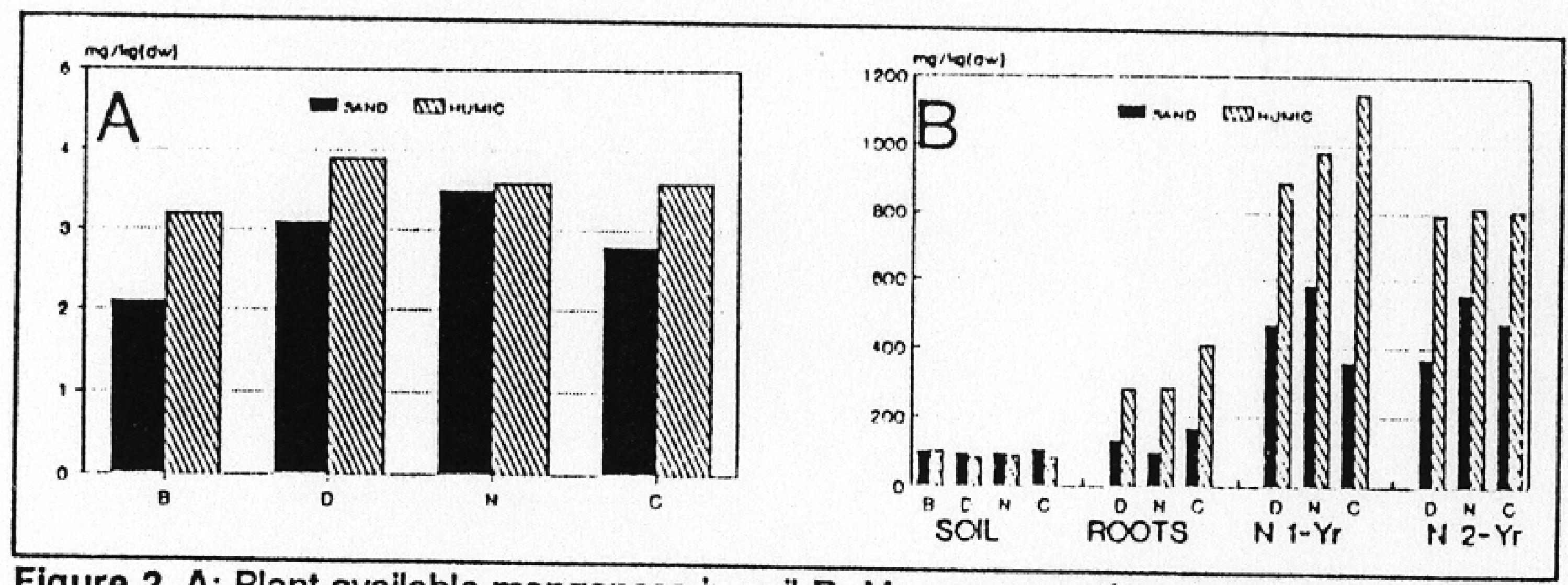

Figure 2. A: Plant-available manganese in soil B: $M n$ concentrations in soil (tot $\mathrm{Mn}$ ) and in plant roots and needles of one year and two years of age. (Legends as in Fig. 1).

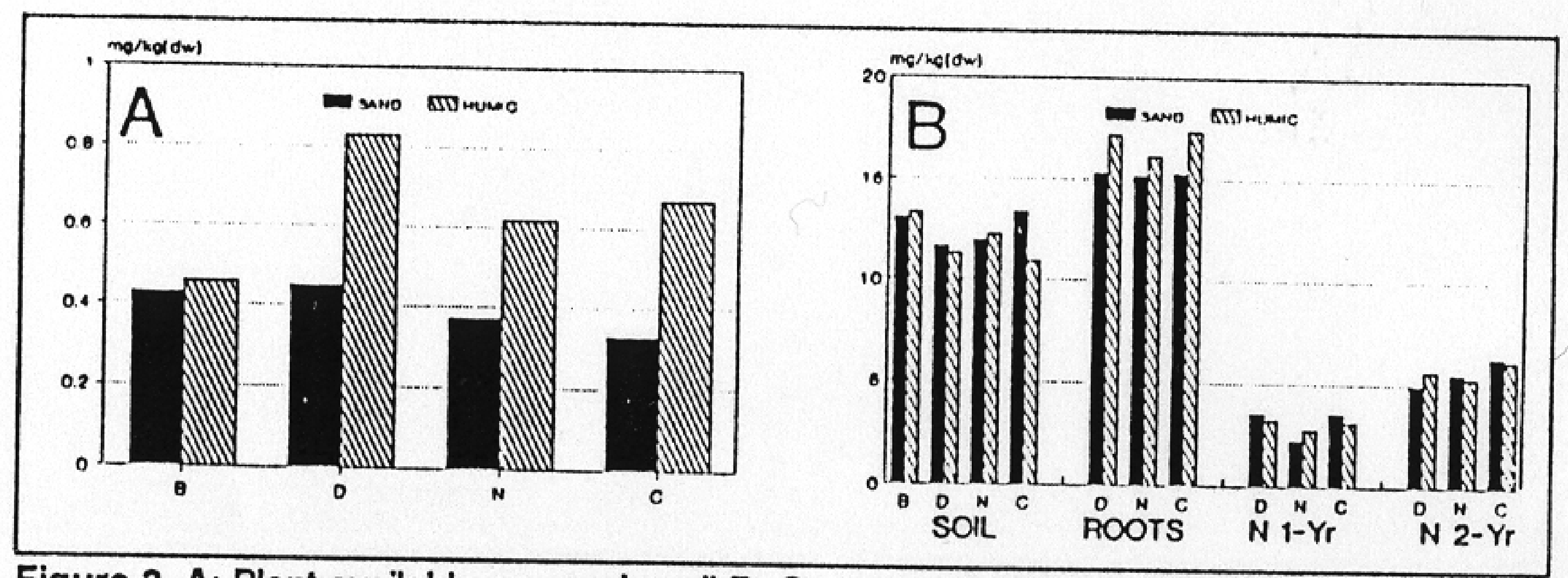

Figure 3. A: Plant-available copper in soil B: Cu concentrations in soil (tot $\mathrm{Cu}$ ) and in plant roots and needles of one year and two years of age. (Legends as in Fig. 1).

Aluminium concentrated in plant roots (Fig. 5). It is difficult to say if the $\mathrm{Al}$ levels in roots were toxic, because the critical Al levels are extremely difficult to define (Hutchinson et al. 1986). Also, Al tolerance changes with many variables including plant age (Joslin et al. 1988). The Al concentrations were, however, not affected by the acid treatments or the soil organic matter content. 


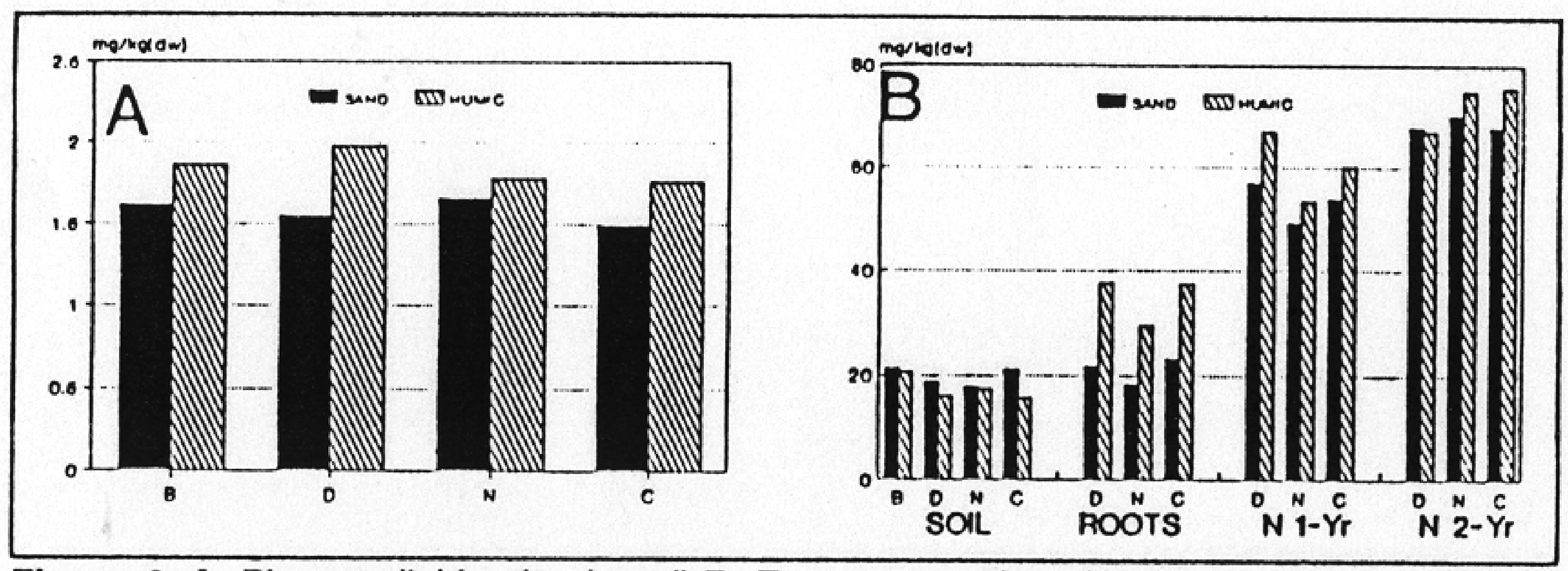

Figure 4. A: Plant-available zinc in soil B: $\mathrm{Zn}$ concentrations in soil (tot $\mathrm{Zn}$ ) and in plant roots and needles of one year and two years of age. (Legends as in Fig. 1).

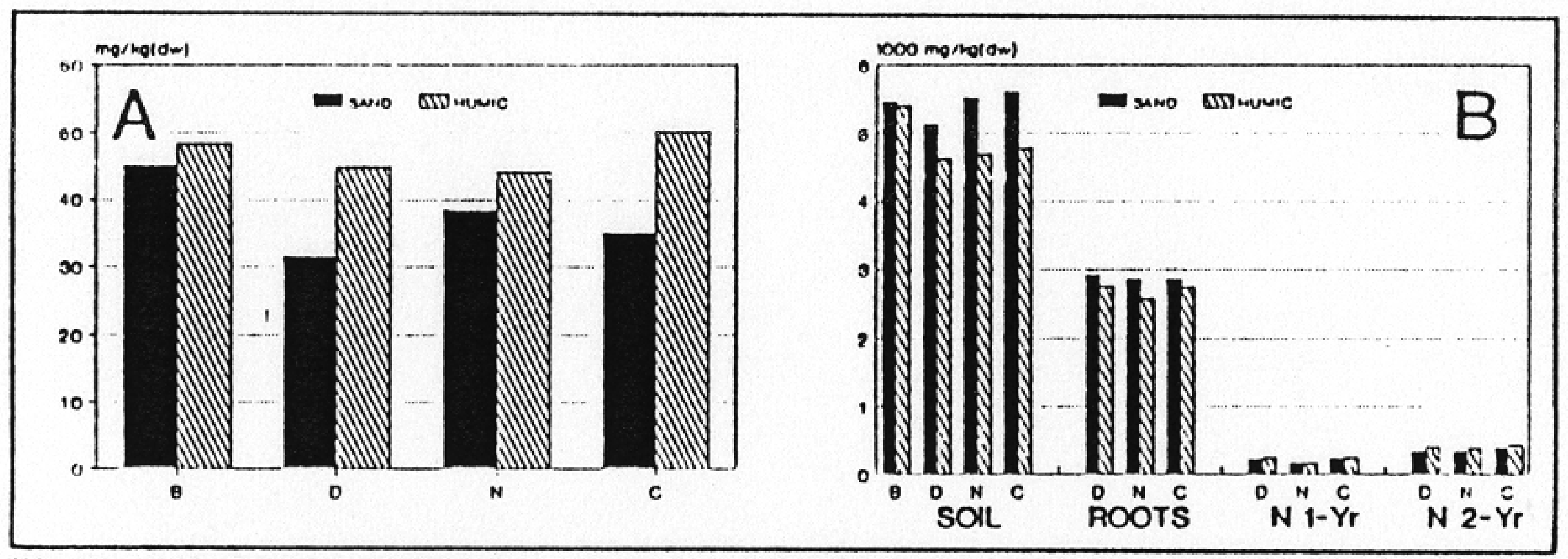

Figure 5. A: Plant-available aluminium in soil B: Al concentrations in soil (tot $\mathrm{Al}$ ) and in plant roots and needles of one year and two years of age. (Legends as in Fig. 1).

It has been claimed that $\mathrm{Al}$ is not transferred from roots to leaves in $\mathrm{Al}$ sensitive species (Foy 1974). Norway spruce has been classified as an Alsensitive plant, but exact critical levels have not been presented (Godbold and Kettner 1991). Also the role of mycorrhizae in plant uptake of $\mathrm{Al}$ is incompletely known.

The plants accumulated cadmium mainly in the roots (Fig. 6). Cd is usually easily mobilized at decreasing soil $\mathrm{pH}$. In our study soil $\mathrm{pH}$ was not affected by the treatments.

Artificial acidification had no significant effect on metal levels of Picea abies. Organic matter in the soil had no clear effect on metal levels except on $\mathrm{Mn}$ levels in roots and needles. The results of corresponding studies are contradictory: some obtained similar results (Lodenius and Malm 1990, Carlson and Ragsdale 1988) while others obtained the opposite (Wyttenbach et al. 1991). This would support the idea that metal absorption into plants is dependent on so many soil variables that equivalent results are not possible unless the conditions are absolutely equal. Some studies indicate that metal mobilization and absorption into plants would be clearly $\mathrm{pH}$-dependent, but $\mathrm{pH}$ would be decisive only at very low $\mathrm{pH}$ values (Carlson and Ragsdale 1988). 


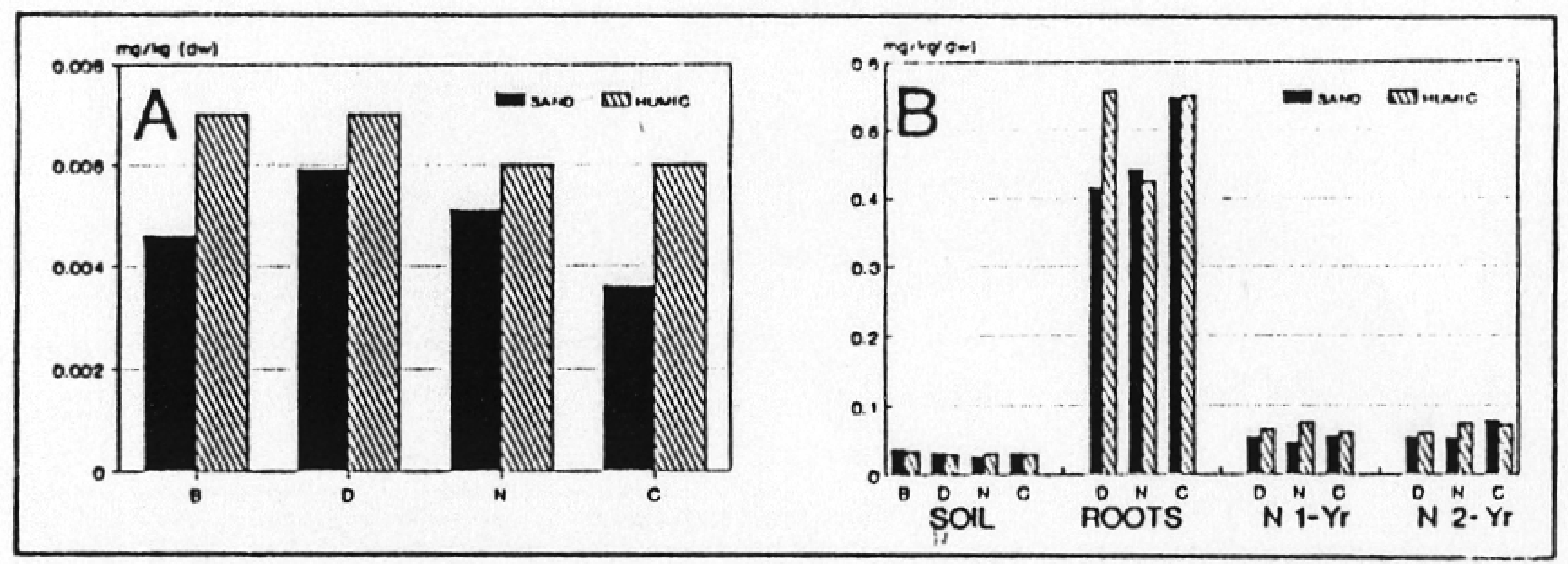

Figure 6. A: Plant-available cadmium in soil B: Cd concentrations in soil (tot $\mathrm{Cd}$ ) and in plant roots and needles of one year and two years of age. (Legends as in Fig. 1).

The metal levels of plants are usually related to plant-available metal concentrations in soil (Kabata-Pendias 1992). In our study the plant-available metal concentrations did not increase significantly during the test. It was obvious that the buffering capacity of the soil was high enough to prevent the changes in $\mathrm{pH}$ value. Norway spruce also grows in naturally acid soils and must thus be adapted to acidic soils.

Although no clear trend in metal accumulation by seedlings was detected, it would be an oversimplification to claim that metals do not play any role as a stress factor in forest ecosystems. It is obvious that acidification as a process is so slow that short time tests cannot show any changes in plant metal levels. Metal problems in terrestrial ecosystems probably depend on how long the buffering capacity in soils is able to bind the increasing amounts of mobilized metals.

The exact role of metals in forest ecosystems is relatively unclear. The difficulties in interpreting the role of different metal concentrations in plant tissues are well known (Verklej and Schat 1989, Kabata-Pendias 1992). Determining the exact critical levels for certain plants is extremely difficult and would require studies at the cellular or even molecular level (MacNicol and Beckett 1985). Many metal toxicity tests are performed using a liquid medium and their applications in the natural environment is thus problematic.

Also, tolerance mechanisms complicate the assessment of metal stress to the organisms. In assessing the metal toxicity to plants, metal sensitivity is an essential factor. No known tolerance mechanism, however, explains completely the metal tolerance of higher plants (Verklej and Schat 1990). The role of mycorrhizae as a tolerance mechanism against metals is still unclear. It seems that some mycorrhizal species increase the hosts' metal absorption and some even seem to prevent it (Dixon and Buschena 1988). Mycorrhizae can also suffer from gaseous air pollutants. The final effect depends on the combined effects of all stress factors. 
Chemical reactions of metals and humic substances in soils should be studied in more detail. For example, the chemical and physical properties of humic substances have been studied for more than 200 years, but their nature as a group is still poorly understood (Livens 1991). Metal-humus complexes are, however, one essential factor determining the amount of plant-available metals in the soil. It seems unlikely that metal toxicity would be the dominant causative factor in forest decline. However, over long time periods they cannot be excluded as a potential contributing stress factor on forest ecosystems.

Acknowledgments. This work was supported by The Academy of Finland. We are also indebted to Jukka Malm, Esa Tulisalo, Anna-Liisa Lodenius and Marjo-Riitta Kojo for technical assistance.

\section{REFERENCES}

Bergkvist B (1987) Soil solution chemistry and metal budgets of spruce forest ecosystems in S. Sweden. Water Air Soil Pollut 38:131-156

Carlson C, Ragsdale HL (1988) Effects of simulated acid precipitation on cadmium and zinc-amended soil and soil-pine systems. Water Air Soil Pollut 42:329-339

Dixon RK, Buschena CA (1988) Response of ectomycorrhizal Pinus bauksiana and Picea glauca to heavy metals in soil. Plant Soil 105:265-271

Foy CD (1974) Effects of aluminium on plant growth. In: Carson EW (ed) The Plant Root and its Environment. Univ. Press, Virginia, Charlottesville, USA Godbold DL, Hüttermann A (1986) The uptake of mercury and lead to spruce (Picea abier Karst.) Seedlings. Water Air Soil Pollut 31: 509-515

Godbold DI, Kettner C (1991) Use of root elongation studies to determine aluminium and lead toxity in Picea abies seedlings. J Plant Physiol 138:231235

Hewitt EJ (1983) A perspective of mineral nutrition: essential and functional metals, in plants. In: Robb DA, Pierpoint WS (eds) Metals and micronutrients: Uptake and Utilization by Plants. Academic Press, London

Hutchinson TC, Bozic L, Munoz-Vega G (1986) Responses of five species of conifer seedlings to aluminium stress. Water Air Soil Pollut 31:283-294

Joslin JD, Kelly JM, Wolfte MH, Rustad LE (1988) Elemental patterns in root and foliage of mature spruce across a gradient of soil aluminium. Water Air Soil Pollut 40:375-390

Kabata-Pendias A (1992) Trace elements in soils and plants (2. ed). CRC Press, Boca Raton, Florida, 365 p.

Krause GHM, Arndt U, Brandt CJ, Bucher J, Kenk G, Matzner E (1986) Forest decline in Europe: development and possible causes. Water Air Soil Pollut 31:647-668

Livens FR (1991) Chemical reactions of metals with humic material. Environ Pollut 70:183-208

Lodenius M, Autio S (1989) Effects of acidification on the mobilization of cadmium and mercury from soils. Arch Environ Contam Toxicol 18:261-267 
Lodenius M, Malm J (1990) Influence of acidification on metal uptake in plants. In: Kauppi P, Anttila P, Kenttämies K (eds) Acidification In Finland. Springer-Verlag, Berlin, Heidelberg, p 495-503

MacNicol RD, Beckett PHT (1985) Critical tissue concentrations of potentially toxic elements. Plant Soil 85:107-129

Martin MH, Coughtrey PJ (1982) Biological monitoring of heavy metal pollution. Land and air. Applied Science Publ. London, New York. $475 \mathrm{p}$ Schulze ED (1989) Air pollution and forest decline in a spruce (Picea Abies) forest. Science 244:776-783

Smith MW, Brennan E (1984) Responce of silver maple seedlings to an acute dose of root applied cadmium. Forest Sci 30:582-586

Verklej JAC, Schat H (1990) Mechanisms of metal tolerance in higher plants. In: Shaw AJ (ed) Heavy Metal Tolerance in Plants: Evolutionary Aspects. CRC Press, Boca Raton, Florida, p 355

Wyttenbach A, Tobler R, Bajo S (1991) Correlations between soil pH and metal contents in needles of Norway spruce. Water Air Soil Pollut 57-58:

217-226 